\title{
ANALISIS RISK BASED BANK RATING (RBBR) UNTUK MENGUKUR TINGKAT KESEHATAN BANK SYARIAH DI INDONESIA
}

\author{
Nardi Sunardi ${ }^{1)}$ \\ 1) dosen universitas pamulang, email : sunardi.unpam@gmail.com
}

\section{ARTICLES INFORMATION}

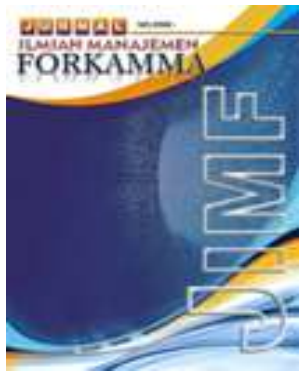

JURNAL ILMIAH MANAJEMEN FORKAMMA

\author{
Vol.1, No.2, Februari 2018 \\ Halaman : $50-66$ \\ (c) LPPM \& FORKAMMA
}

Prodi Magister Manajemen UNVERSITAS PAMULANG

ISSN (online) : 2599-171X

ISSN (print) : :2598-9545

\section{Keyword :}

Tingkat Kesehatan Bank, Metode Risk Based Bank Rating (RBBR) Bank Syariah di Indonesia

JEL. classification :

C31, E50

\section{Contact Author :}

PRODI
MAGISTER MANAJEMEN \&
FORKAMMA UNPAM
JL.Surya Kencana No.1 Pamulang
Tangerang Selatan - Banten
Telp. (021) 7412566, Fax (021) 7412491
Email :
jurnalforkamma.unpam@gmail.com

Penelitian ini bertujuan untuk mengetahui kondisi profil risiko, Good Corporate Governance (GCG), rentabilitas, permodalan dan tingkat kesehatan Bank Syariah di Indonesia dinilai dengan metode Risk Based Bank Rating (RBBR) selama periode 20122016. Jenis penelitian deskriptif dengan pendekatan kuantitatif digunakan dalam penelitian ini. Hasil penelitian menunjukkan bahwa faktor profil risiko bank syariah di Indonesia dengan faktor risk profile atas resiko kredit dengan rasio rata-rata secara keseluruhan NPF dengan predikat Sehat. Risiko Likuiditas menunjukkan bahwa rata-rata secara keseluruhan Financing to Deposit Ratio (FDR) dengan predikat Kurang Sehat, Good Coorporate Governance diperoleh hasil analisis self assessment yaitu dengan nilai komposit $1.83 \%$ dengan predikat Baik, faktor earning (rentabilitas) dengan Return On Asset (ROA) predikat Kurang Sehat, analisis modal dengan Capital Adequency Ratio (CAR) predikat Sangat Sehat, Metode Risk Based Bank Rating (RBBR) menunjukkan nilai PK 1 dengan predikat Cukup Sehat. berdasarkan Pasal 2 Peraturan bank Indonesia No. 13/1/PBI/2011 dan sesuai yang telah dijelaskan dalam SE BI No. 13/24/DPNP 25 Oktober 2011.

This study aims to determine the condition of risk profile, Good Corporate Governance (GCG), profitability, capital and Bank Syariah health rating in Indonesia assessed by Risk Based Bank Rating (RBBR) method during 2012-2016 period. Type of descriptive research with quantitative approach used in this study. The results showed that the risk factor of sharia banks in Indonesia with risk profile factor on credit risk with the overall average ratio of NPF with Healthy predicate. Liquidity risk indicates that the overall average Financing to Deposit Ratio (FDR) with the predicate of Less Healthy, Good Corporate Governance obtained the results of self assessment analysis with a composite value of $1.83 \%$ with good predicate, earnings factor (earnings) with Return On Asset (ROA ) predicate Less Healthy, capital analysis with Capital Adequency Ratio (CAR) predicate Very Healthy, Risk Based Bank Rating Method (RBBR) shows the value of PK 1 with predicate Healthy Enough. based on Article 2 of Bank Indonesia Regulation no. 13/1 / PBI / 2011 and as described in Bank Indonesia Circular Letter No. 13/24 / DPNP October 25, 2011. 


\section{A. Pendahuluan}

Bank kini menjadi lebih fleksibel dalam layanan yang diberikan, bukan sekedar sebagai tempat penyimpanan uang bagi pihak yang kelebihan dan (surplus fund) dan sebagai sumber dana bagi pihak yang memerlukan dana (defisit fund). Produk dan jasa perbankan yang ditawarkan juga semakin beraneka dan memberikan kemudahan dalam bertransaksi. Hal tersebut dilakukan untuk menarik nasabah sebanyak-banyaknya.

Bank merupakan suatu lembaga keuangan yang beperan penting dalam menjalankan sebuah kegiatan perekonomia suatu negara yang perkembangannya saat ini semakin kompleks. Secara umum, bank-bank di Indonesia terdiri dari bank konvesional dan bank syariah. Banyak saat ini bank-bank konvensional telah mengkonversi bank syariah untuk menarik nasabah sebanyak-banyaknya. Beberapa alasan mengapa bank konvensional melirik dan bahkan mengkonversi untuk membuka bank syariah adalah karena mayoritas penduduk di Indonesia menganut agama islam yang mana mereka telah menyadari adanya keharamanan pada bunga bank konvensional yang telah dikeluarkan fatwanya oleh MUI. Bank syariah menganut sistem bagi hasil yang diyakini lebih menguntungkan dibandingkan bunga dari bank konvensional.

Pengawasan bank diperlukan untuk memantau dan memeriksa pengelolaan yang sesuai dengan ketentuan perbankan. Pengawasan terhadap bank juga dilakukan untuk mengetahui kinerja bank dan mengukur tingkat kesehatan. Kesehatan bank dinilai sebagai kemampuan suatu bank dalam melakukan kegiatan operasional perbankan secara normal dan mampu memenuhi semua kewajibannya dengan baik, sesuai dengan peraturan yang berlaku. Bank Indonesia menerbitkan Peraturan Bank Indonesia No. 13/1/PBI/2011 mengenai tingkat kesehatan bank yang diukur dengan menggunakan metode Risk Based Bank Rating (RBBR).

RBBR terdiri dari empat faktor yakni, profil risiko (risk profie), good corporate governance (GCG), rentabilitas (earning), permodalan (capita). Faktor risk profile dilakukan penilaian terhadap risiko inheren dan penerapan manajemen risiko dalam kegiatan operasional bank terhadap delapan risiko yakni, risiko kredit, risiko pasar, risiko likuiditas, risiko operasional, risiko hukum, risiko stratejik, risiko kepatuhan, dan risiko reputasi. Faktor GCG dilakukan penilaian terhadap kualitas manajemen bank berdasarkan prinsip-prinsip GCG. Faktor earning merupakan penilaian yang meliputi kinerja, sumber, kesinambungan, dan manajemen rentabilitas, rasio yang menunjukkan kinerja rentabilitas yakni Return On Asset (ROA) dan Net Interest Margin (NIM). Berdasarkan SE BI No. 13/24/DPNP menjelaskan bahwa "penilaian atas faktor permodalan meliputi evaluasi terhadap kecukupan permodalan dan kecukupan pengelolaan permodalan", permodalan bank dapat diukur dengan rasio Capital Adequency Ratio (CAR).

Sektor perbankan syariah di Indonesia merupakan salah satu diantara beberapa sektor yang ada di BI Perusahaan yang bergerak dalam sektor perbankan syariah di Indonesia saat ini berkembang dengan pesat. Kemajuan dan perkembangan bisnis ini menjadi daya tarik bagi para investor untuk berinvestasi pada perusahaan sektor perbankan syariah di Indonesia. Investor mengerti bahwa sektor perbankan syariah di Indonesia mempunyai prospek yang baik kedepannya yang mendominasi perbankan di Indonesia dan menguasai hajat hidup banyak orang, maka bank syariah dituntut untuk terus menjaga kesehatannya. Likuidasi atau bangkrutnya suatu bank yang besar dapat menyebabkan bangkrutnya bank yang lain akibat penarikan dana secara tiba-tiba (Latumaerissa, 2012:144). Berdasarkan latar belakang masalah yang dipaparkan, maka peneliti tertarik mengajukan penelitian dengan judul "Analisis Risk Based Bank Rating (RBBR) Untuk Mengukur Tingkat Kesehatan Bank Syariah di Indonesia). 


\section{B. Perumusan Masalah}

Berdasarkan latar belakang masalah di atas maka masalah yang akan dibahas dan dicari jawabannya dalampenelitian ini adalah :

1. Bagaimana tingkat kesehatan perbankan syariah yang ada di Indonesia dinilai dengan metode Risk Based Bank Rating (RBBR) tahun 2012-2016?

2. Bagaimana perbandingan tingkat kesehatan perbankan syariah yang ada di Indonesia dengan deskriptif kuantitatif metode Risk Based Bank Rating (RBBR) tahun 2012 - 2016 ?

\section{Tujuan Penelitian}

Berdasarkan perumusan masalah diatas, maka tujuan yang hendak dicapai dari penelitian ini adalah memperoleh data dan informasi yang tepat untuk menganalisis data. Secara khusus penelitian ini bertujuan untuk:

1. Untuk mengetahui bagaimana tingkat kesehatan perbankan syariah yang ada di Indonesia dinilai dengan metode Risk Based Bank Rating (RBBR) tahun 2012-2016?

2. Untuk mengetahui bagaimana perbandingan tingkat kesehatan perbankan syariah yang ada di Indonesia dengan deskriptif kuantitatif metode Risk Based Bank Rating (RBBR) tahun 2012 - 2016 ?

\section{Landasan Teori}

\section{Bank}

\section{Pengertian Bank}

Menurut Undang-undang RI No.10 Tahun 1998 mengenai perbankan, "Bank adalah badan usaha yang menghimpun dana dari masyarakat dalam bentuk simpanan dan menyalurkannya kepada masyarakat dalam bentuk kredit dan atau bentuk lainnya dalam rangka meningkatkan taraf hidup rakyat banyak. Menurut Kasmir (2015:12) dalam bukunya yang berjudul "Manajemen Perbankan", bank adalah lembaga keuangan yang kegiatan utamanya adalah menghimpun dana dari masyarakat dan menyalurkannya kembali dan tersebut ke masyarakat serta memberikan jasa bank lainnya.

\section{Fungsi Bank}

Secara spesifik fungsi bank menurut Budisantoso dan Triandaru (2006) adalah sebagai berikut:

a. Agent of Trust, atau lembaga berlandaskan kepercayaan (trust) masyarakat untuk bersedia menyimpan dananya di bank maupun kepercayaan bank terhadap debitur dalam penyaluran dananya.

b. Agent of Development, atau lembaga yang memobilisasi dan untuk pembangunan ekonomi dalam bentuk operasional kegiatan masyarakat yang berkaitan dalam bentuk operasional kegiatan masyarakat yang berkaitan dengan sektor rill yang sangat terkait erat dengan kegiatan ekonomi masyarakat. Perekonomian akan tumbuh dengan baik apabila peran agent of development dari bank dapat terlaksana dengan baik. 
c. Agent of servis, adalah lembaga yang memobilisasi dan untuk pembangunan ekonomi dalam hal penawaran jasa perbankan, dalam bentuk penerimaan uang, penitipan barang berharga dan atau pemberian jaminan bank.

\section{Bank Syariah}

Bank Syariah adalah bank yang menjalankan kegiatan usahanya berdasarkan prinsip syariah yang terdiri atas Bank Umum Syariah dan Bank Pembiayaan Syariah (Muthaher, 2012:14). Prinsip dasar dari perbankan syariah dalam menjalankan sistem operasionalnya mengutamakan keadilan yang ditujukan untuk semua pihak, baik pihak kreditur maupun pihak debitur. Adapun prinsip-prinsip dasar dari bank syariah adalah: (a) Larangan terhadap transaksi yang mengandung barang atau jasa yang diharamkan; (b) Larangan terhadap transaksi yang diharamkan sistem dan prosedur perolehan keuntungannya. Yaya. et.al (2014:35) menyebutkan ada beberapa hal yang masuk ketagori transaksi yang diharamkan karena sistem dan prosedur perolehan keuntungan tersebut, antara lain: (1) Tadlis (ketidaktahuan satu pihak), (2) Gharar (ketidaktahuan kedua pihak), (3) Ikhtikar (rekayasa pasar dalam pasokan), (4)Bai' najasy (rekayasa pasar dalam permintaan), (5)Masyir (judi), dan, (6) Riba.

\section{Laporan Keuangan}

Laporan keuangan adalah ringkasan dari proses pencatatan transaksi-transaksi keuangan perusahaan yang sistematis mengenai posisi keuangan perusahaan pada suatu saat tertentu. Tujuan pembuatan laporan keuangan adalah untuk menggambarkan kondisi keuangan perusahaan. Tujuan lainnya adalah untuk menilai kinerja manajemen bank yang bersangkutan.

\section{Kesehatan Bank}

Perbankan harus dinilai kesehatannya agar tetap prima dalam melayani nasabahnya. Penilaian kesehatan bank dilakukan setiap tahun untuk melihat adanya peningkatan atau penurunan kesehatan. Kesehatan bank merupakan kepentingan semua pihak yang terkait yakni, pemilik, manajemen, masyarakat (nasabah pengguna jasa), dan Bank Indonesia selaku pengawas dan pembinan perbankan. Sistem penilaian dalam menetapkan tingkat kesehatan bank didasarkan pada pemberian "reward system" adalah dengan memberikan penilaian menggunakan ukuran (1-100) dalam pemeringkatan baik dengan skala kredit maupun dengan skala nilai rasio dan digolongkan dalan 5 peringkat atau disingkat $(\mathrm{PK})$ :

\section{Peringkat Komposit}

\begin{tabular}{|c|l|}
\hline $\begin{array}{c}\text { Peringkat } \\
\text { Komposit }\end{array}$ & \multicolumn{1}{|c|}{ Keterangan } \\
\hline 1 & $\begin{array}{l}\text { Mencerminkan bahwa bank tergolong sangat sehat dan mampu mengatasi } \\
\text { pengaruh negatif kondisi perekonomian dan industri keuangan. }\end{array}$ \\
\hline 2 & $\begin{array}{l}\text { Mencerminkan bahwa bank tergolong sehat dan mampu mengatasi } \\
\text { pengaruh negatif namun bank masih memiliki kelemahan-kelemahan yang } \\
\text { dapat segera diatasi oleh tindakan rutin. }\end{array}$ \\
\hline 3 & $\begin{array}{l}\text { Mencerminkan bahwa bank tergolong cukup sehat namun terdapat } \\
\text { kelemahan yang dapat menyebabkan peringkat kompositnya memburuk } \\
\text { apabila bank tidak segera melakukan tindakan korektif. }\end{array}$ \\
\hline 4 & $\begin{array}{l}\text { Mencerminkan bahwa bank tergolong kurang sehat dan sensitif terhadap } \\
\text { negatif kondisi perekonomian dan industri keuangan atau bank meiliki }\end{array}$ \\
\hline
\end{tabular}




\begin{tabular}{|c|l|}
\hline & $\begin{array}{l}\text { kelemahan keuangan yang serius atau kombinasi dari kondisi beberapa } \\
\text { faktor yang tidak memuaskan, yang apabila tidak dilakukan tindakan } \\
\text { korektif yang efektif berpotensi mengalami kesulitan yang membahayakan } \\
\text { kelangsungan usahanya. }\end{array}$ \\
\hline 5 & $\begin{array}{l}\text { Mencerminkan bahwa bank tergolong tidak sehat dan sangat sensitif } \\
\text { terhadap pengaruh negatif kondisi perekonomian dan industri keuangan } \\
\text { serta mengalami kesulitan yang membahayakan kelangsungan usahanya. }\end{array}$ \\
\hline
\end{tabular}

Sumber: Peraturan Bank Indonesia No. 6/10/PBI tanggal 12 April 2004

Penggolongan tingkat kesehatan bank dibagi dalam 5 kategori yaitu: sangat sehat, sehat, cukup sehat, kurang sehat dan tidak sehat. Dalam rangka penerapan ketentuan yang memerlukan persyaratan tingkat kesehatan bank maka predikat Tingkat Kesehatan Bank disesuaikan dengan ketentuan dalam Surat Edaran Bank Indonesia No. 6/23/DPNP tanggal 31 Mei 2004 sebagai berikut:

a. Untuk predikat Tingkat Kesehatan "Sehat" dipersamakan dengan peringkat komposit 1 (PK-1) atau peringkat komposit 2 (PK-2).

b. Untuk predikat Tingkat Kesehatan "Cukup Sehat" dipersamakan dengan peringkat komposit 3 (PK-3).

c. Untuk predikat Tingkat Kesehatan "Kurang Sehat" dipersamakan dengan peringkat komposit 4 (PK-4).

d. Untuk predikat Tingkat Kesehatan "Tidak Sehat" dipersamakan dengan peringkat komposit 5 (PK-5).

\section{Metode Risk Based Bank Rating}

Berdasarkan Pasal 2 Peraturan bank Indonesia No. 13/1/PBI/2011 disebutkan bank wajib melakukan penilaian tingkat kesehatan bank dengan menggunakan pendekatan risko (Risk Based Bank Rating) baik secara individual ataupun konsolidasi.

Pada dasarnya sesuai yang telah dijelaskan dalam SE BI No. 13/24/DPNP 25 Oktober 2011,metode RBBR ini menitikberatkan pertimbangan kesehatan bank umum berdasarkan prinsip kehati-hatian dan manajemen resiko. Hal ini sangat selaras dengan kondisi perekonomian saat ini. Unsur resiko yang harus dipikul oleh bank, keadaan yang sering tidak stabil, inflasi yang tinggi, kondisi nasabah yang sering dengan cepat mengalami perubahan, menjadi alasan unsur kehati-hatian dalam menjalankan operasional bank.

Peraturan tersebut menggantikan peraturan sebelumnya mengenai penilaian tingkat kesehatan bank dengan menggunakan faktor CAMEL. Metode RBBR berdasarkan SE BI No. 13/24/DPNP terdiri dari empat faktor yakni:

\section{Profil Risiko (Risk Profile)}

Berdasarkan PBI No. 13/1/PBI/2011 bank melakukan penilaian terhadap risiko inheren dan kualitas penerapan manajemen risiko dalam kegiatan operasional terhadap delapan risiko, yakni risiko kredit, risiko pasar, risiko likuiditas, risiko operasional, risiko hukum, risiko stratejik, risiko kepatuhan, dan risiko reputasi. Penelitian ini mengukur tiga risiko pada faktor risk profile menggunakan rasio Non Performing Financing (NPF) untuk mengukur risiko kredit, rasio Interest Rate Risk (IRR) untuk mengukur risiko pasar, dan rasio Financing to Deposit Ratio (FDR)) untuk mengukur risiko likuiditas.

a. Risiko kredit dapat dihitung menggunakan rumus sebagai berikut :

Non Performing Financing $(N P F)=\frac{\text { Kredit Bermasalah }}{\text { Total kredit }} \times 100 \%$

Sumber: Lampiran SE BI 13/24/DPNP/2011 
Tabel 1 Predikat Non Performing Loan Bank

\begin{tabular}{|c|c|c|}
\hline No. & Rasio & Predikat \\
\hline 1 & $0 \%<\mathrm{NPF}<2 \%$ & Sangat Sehat \\
\hline 2 & $2 \% \leq \mathrm{NPF}<5 \%$ & Sehat \\
\hline 3 & $5 \% \leq \mathrm{NPF}<8 \%$ & Cukup Sehat \\
\hline 4 & $8 \%<\mathrm{NPF} \leq 11 \%$ & Kurang Sehat \\
\hline 5 & $\mathrm{NPF}>11 \%$ & Tidak Sehat \\
\hline
\end{tabular}

b. Risiko Likuiditas dapat dihitung menggunakan Financing to Deposit Ratio (FDR) sebagai berikut :

Financing to Deposit Ratio $(F D R)=\frac{\text { Total Kredit }}{\text { Dana Pihak Ketiga }} \times 100 \%$

Sumber: Lampiran SE BI 13/24/DPNP/2011

Tabel 2 Predikat Loan to Deposit Ratio Bank

\begin{tabular}{|c|c|c|}
\hline No. & Rasio & Predikat \\
\hline 1 & $50 \%<$ FDR $\leq 75 \%$ & Sangat Sehat \\
\hline 2 & $75 \%<$ FDR $\leq 85 \%$ & Sehat \\
\hline 3 & $85 \%<$ FDR $\leq 100 \%$ & Cukup Sehat \\
\hline 4 & $100 \%<$ FDR $\leq 120 \%$ & Kurang Sehat \\
\hline 5 & FDR $>120 \%$ & Tidak Sehat \\
\hline
\end{tabular}

Sumber SE BI No. 6/23/DPNP

\section{Good Corporate Governance (GCG)}

Penilain pelaksanakan GCG bank mempertimbangkan faktor-faktor penilaian GCG secara komprehensif dan terstruktur, mencakup governance structur, governance process, dan governance outcome. Berdasarkan SE BI No. 15/15/DPNP Tahun 2013 bank diharuskan melakukan penilan sendiri (self assessment) Tingkat Kesehatan Bank dengan menggunakan pendekatan Risiko (Risk Based Bank Rating/RBBR) Bank Indonesia mengenai penilaian Tingkat Kesehatan Bank Umum dengan menggunakan pendekatan risiko (RBBR), penilaian terhadap pelaksanaan GCG yang berlandasan pada 5 ( lima ) prinsip dasar tersebut dikelompokan dalam suatu governance system yang terdiri dari 3 (tiga) aspek governance, yaitu governance structure, governance process dan governance outcome.

Tabel 3 Peringkat Komposit GCG

\begin{tabular}{|c|c|c|}
\hline No. & Rasio & Predikat \\
\hline 1 & Nilai Komposit $<1,5$ & Sangat Baik \\
\hline 2 & $1,5<$ Nilai Komposit $<2,5$ & Baik \\
\hline 3 & $2,5<$ Nilai Komposit $<3,5$ & Cukup Baik \\
\hline 4 & $3,5<$ Nilai Komposit $<4,5$ & Kurang Baik \\
\hline 5 & Nilai Komposit $>4,5$ & Tidak Baik \\
\hline
\end{tabular}

Sumber: Lampiran SE BI 13/24/DPNP/2011 


\section{Rentabilitas (earning)}

Penilaian earning bank milik pemerintah pusat menggunakan parameter diantaranya adalah:

\section{a. Return On Asset (ROA)}

$$
\text { Return On Asset (ROA) }=\frac{\text { Laba Sebelum Pajak }}{\text { Rata-Rata Total Aset }} \times 100 \%
$$

Sumber: Lampiran SE BI 13/24/DPNP/2011

Tabel 4 Predikat Bank Berdasarkan ROA

\begin{tabular}{|c|c|c|}
\hline No. & Rasio & Predikat \\
\hline 1 & $2 \%<\mathrm{ROA}$ & Sangat Sehat \\
\hline 2 & $1,25 \%<\mathrm{ROA} \leq 2 \%$ & Sehat \\
\hline 3 & $0,5 \%<\mathrm{ROA} \leq 1,25 \%$ & Cukup Sehat \\
\hline 4 & $0 \%<\mathrm{ROA} \leq 0,5 \%$ & Kurang Sehat \\
\hline 5 & $\mathrm{ROA} \leq 0 \%$ & Tidak Sehat \\
\hline
\end{tabular}

Sumber: Kodifikasi penilaian kesehatan bank

\section{b. Net Interest Margin (NIM)}

$$
\text { Net Interest Margin (NIM) }=\frac{\text { Pendapatan Bunga Bersih }}{\text { Rata-Rata Total Earning Aset }} \times 100 \%
$$

Sumber: Lampiran SE BI 13/24/DPNP/2011

Tabel 5 Predikat Kesehatan Berdasarkan NIM

\begin{tabular}{|c|c|c|}
\hline No. & Rasio & Predikat \\
\hline 1 & $3 \%<\mathrm{NIM}$ & Sangat Sehat \\
\hline 2 & $2 \%<\mathrm{NIM} \leq 3 \%$ & Sehat \\
\hline 3 & $1,5 \%<\mathrm{NIM} \leq 2 \%$ & Cukup Sehat \\
\hline 4 & $1 \%<\mathrm{NIM} \leq 1,5 \%$ & Kurang Sehat \\
\hline 5 & $\mathrm{NIM} \leq 1 \%$ & Tidak Sehat \\
\hline
\end{tabular}

\section{c. Beban Operasional Pendapatan Operasional (BOPO)}

BOPO merupakan perbandingan antara beban operasional terhadap pendapatan operasional. Rasio ini digunakan untuk mengukur tingkat efisiensi dan kemampuan bank dalam melakukan kegiatan operasionalnya (Kaligis, 2013). Rasio BOPO dapat dihitung menggunakan rumus sebagai berikut:

$$
B O P O=\frac{\text { Biaya Operasional }}{\text { Pendapatan Operasional }} \times 100 \%
$$

Sumber: Lampiran SE BI 13/24/DPNP/2011 
Tabel 6 Predikat Kesehatan Berdasarkan BOPO

\begin{tabular}{|c|c|c|}
\hline No. & Rasio & Predikat \\
\hline 1 & BOPO $\leq 94 \%$ & Sangat Sehat \\
\hline 2 & $94 \%<$ BOPO $\leq 95 \%$ & Sehat \\
\hline 3 & $95 \%<$ BOPO $\leq 96 \%$ & Cukup Sehat \\
\hline 4 & $96 \%<$ BOPO $\leq 97 \%$ & Kurang Sehat \\
\hline 5 & BOPO $>97 \%$ & Tidak Sehat \\
\hline
\end{tabular}

Sumber : Lampiran SE BI 13/24/DPNP/2011

\section{Permodalan (Capital)}

Rasio Capital Adequency Ratio (CAR) dapat digunakan untuk mengukur kecukupan modal yang dimiliki bank dan pemenuhan Kewajiban Penyediaan Modal Minimum (KPMM). Rumus CAR yang digunakan adalah :

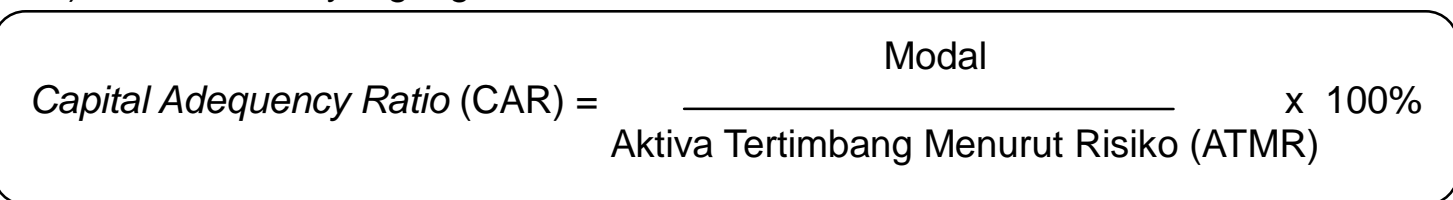

Sumber: Lampiran SE BI 13/24/DPNP/2011

Tabel 7 Predikat Kesehatan Berdasarkan CAR

\begin{tabular}{|c|c|c|}
\hline No. & Rasio & Predikat \\
\hline 1 & $12 \%<\mathrm{CAR}$ & Sangat Sehat \\
\hline 2 & $9 \%<\mathrm{CAR} \leq 12 \%$ & Sehat \\
\hline 3 & $8 \%<\mathrm{CAR} \leq 9 \%$ & Cukup Sehat \\
\hline 4 & $6 \%<\mathrm{CAR} \leq 8 \%$ & Kurang Sehat \\
\hline 5 & CAR $\leq \%$ & Tidak Sehat \\
\hline
\end{tabular}

Sumber: Kodifikasi penilaian kesehatan bank

\section{E. Metodologi}

\section{Penentuan Populasi dan Sampel}

Jenis Penelitian ini menggunakan pendekatan kuantitatif yang merupakan masingmasing variabel maupun antar variabel didasari pada skala pengukuran kuantitatif.

Populasi dipilih sampel dengan menggunakan teknik purposive sampling. Dasi teknik tersebut diperoleh 11 Bank syariah yang menjadi penelitian. Dalam penelitian ini, untuk menentukan sampel digunakan kriteria-kriteria sebagai berikut:

a. Bank Umum Syariah (BUS) yang terdaftar di Otoritas Jasa Keuangan (OJK) pada periode 2012-2016..

b. Bank Umum harus tetap beroperasi selama periode penelitian tahun 2012-2016.

c. Bank yang memiliki data keuangan annual report lengkap rasio keuangan NPL, LDR, ROA, NIM, BOPO, CAR dan laporan pelaksanaan hasil self assessment Good Coorporate Governance tahun 2012 - 2016. 
Tabel 8 Populasi Penelitian

\begin{tabular}{|c|c|l|}
\hline No. & KODE & \multicolumn{1}{c|}{ Bank Umum Syariah } \\
\hline 1 & BMI & PT Bank Muamalat Indonesia \\
\hline 2 & BSM & PT Bank Syariah Mandiri \\
\hline 3 & BMS & PT Bank Mega Syariah \\
\hline 4 & BRIS & PT Bank BRI Syariah \\
\hline 5 & BSBU & PT Bank Syariah Bukopin \\
\hline 6 & BPS & PT Bank Panin Syariah \\
\hline 7 & BVS & PT Bank Victoria Syariah \\
\hline 8 & BCAS & PT Bank BCA Syariah \\
\hline 9 & BJBS & PT Bank Jabar Banten Syariah \\
\hline 10 & BNIS & PT Bank BNI Syariah \\
\hline 11 & BMSI & PT Bank Maybank Syariah Indonesia \\
\hline
\end{tabular}

Sumber: OJK, (2018)

\section{Sumber Data}

Penelitian ini menggunakan data sekunder yang meliputi laporan keuangan dan publikasi predikat komposit hasil self assesment penerapan GCG tahun 2012-2016 milik Bank Umum Syariah (BUS) yang terdaftar di Otoritas Jasa Keuangan (OJK) pada periode 2012-2016

\section{Teknik Pengumpulan Data}

Penelitian ini menggunakan teknik dokumentasi untuk memperoleh data sekunder yang dibutuhkan. Data-data yang berhubungan dengan obyek penelitian diperoleh dari website resmi Bank Indonesia yaitu www.bi.co.id

\section{Analisis Data}

a. Menganalisis tingkat kesehatan Bank Umum Syariah (BUS) yang terdaftar di Otoritas Jasa Keuangan (OJK) dinilai dengan metode Risk Based Bank Rating (RBBR) tahun 2012- 2016.

b. Menganalisis perbandingan tingkat kesehatan Bank Umum Syariah (BUS) yang terdaftar di Otoritas Jasa Keuangan (OJK) dinilai dengan deskriptif

\section{F. Hasil dan Pembahasan}

Penelitian ini melakukan analisis tingkat kesehatan bank dengan menggunakan metode risk based bank rating (RBBR) dalam penelitian ini ditunjukkan dalam hasil dibawah ini :

\section{Analisis Profil Risiko (Risk Profile)}

Penelitian ini mengukur risiko kredit pada faktor risk profile menggunakan rasio Non Performing Financing (NPF) dan rasio Loan to Deposit Ratio (LDR) untuk mengukur risiko likuiditas.

\section{a. Risiko Kredit}

Berdasarkan Tabel 9 menunjukkan bahwa rata-rata secara keseluruhan NPF Bank Umum Syariah (BUS) yaitu 3.56\% dengan predikat Sehat. NPF tertinggi dimiliki oleh Bank Victoria Syariah dengan nilai rata-rata NPF sebesar $6.22 \%$ dengan predikat Cukup Sehat karena meningkatnya jumlah kredit bermasalah Bank Victoria Syariah. NPF terendah dimiliki oleh Bank BCA Syariah dengan nilai NPF 
sebesar $0.30 \%$ dengan predikat Sangat Sehat karena rendahnya kredit bermasalah yang dimiliki Bank BCA Syariah.

Tabel 9 Kesehatan Bank Syariah Berdasarkan Rasio NPF

\begin{tabular}{|c|l|c|c|c|c|c|c|c|c|}
\hline \multirow{2}{*}{ No. } & \multirow{2}{*}{$\begin{array}{l}\text { Nama Bank Umum } \\
\text { Syariah Indonesia }\end{array}$} & \multicolumn{5}{|c|}{$\begin{array}{c}\text { Non Performing Financing } \\
\text { (NPL/NPF) }\end{array}$} & \multirow{2}{*}{ Rata $^{2}$} & \multirow{2}{*}{ Predikat } & \multirow{2}{*}{ PK } \\
\cline { 3 - 9 } & $\mathbf{2 0 1 2}$ & $\mathbf{2 0 1 3}$ & $\mathbf{2 0 1 4}$ & $\mathbf{2 0 1 5}$ & $\mathbf{2 0 1 6}$ & & & \\
\hline 1 & Bank Muamalat & 2.09 & 4.69 & 6.55 & 7.11 & 3.83 & 4.85 & Sehat & 4 \\
\hline 2 & Bank Syariah Mandiri & 2.82 & 4.32 & 6.84 & 6.06 & 4.92 & 4.99 & Sehat & 4 \\
\hline 3 & Bank Mega Syariah & 2.67 & 2.99 & 3.89 & 4.26 & 3.30 & 3.42 & Sehat & 4 \\
\hline 4 & Bank BRI Syariah & 3.00 & 4.06 & 4.60 & 4.86 & 4.57 & 4.22 & Sehat & 4 \\
\hline 5 & Bank Syariah Bukopin & 4.59 & 4.27 & 4.07 & 2.99 & 3.17 & 3.82 & Sehat & 4 \\
\hline 6 & Bank Panin Syariah & 0.20 & 1.02 & 0.53 & 2.63 & 2.26 & 1.33 & Sangat Sehat & 1 \\
\hline 7 & Bank Victoria Syariah & 3.19 & 3.71 & 7.10 & 9.80 & 7.31 & 6.22 & Cukup Sehat & 3 \\
\hline 8 & Bank BCA Syariah & 0.10 & 0.10 & 0.10 & 0.70 & 0.50 & 0.30 & Sangat Sehat & 1 \\
\hline 9 & Bank BJB Syariah & 4.46 & 1.86 & 5.84 & 6.93 & 1.79 & 4.18 & Sehat & 4 \\
\hline 10 & Bank BNI Syariah & 2.02 & 1.86 & 1.86 & 2.53 & 2.94 & 2.24 & Sehat & 4 \\
\hline 11 & Bank Maybank Syariah & 2.49 & 2.69 & 5.04 & 3.52 & 4.40 & 3.63 & Sehat & 4 \\
\hline & RATA-RATA & $\mathbf{2 . 5 1}$ & $\mathbf{2 . 8 7}$ & $\mathbf{4 . 2 2}$ & $\mathbf{4 . 6 7}$ & $\mathbf{3 . 5 4}$ & $\mathbf{3 . 5 6}$ & Sehat & $\mathbf{4}$ \\
\hline
\end{tabular}

Sumber: Data diolah (2018)

b. Risiko Likuiditas

Berdasarkan Tabel 10 menunjukkan bahwa rata-rata secara keseluruhan Financing to Deposit Ratio (FDR/LDR) Bank Umum Syariah (BUS) yaitu 101.83\% dengan predikat Kurang Sehat. FDR tertinggi dimiliki oleh Bank Maybank Syariah dengan nilai rata-rata FDR sebesar $186.20 \%$ dengan predikat Tidak Sehat Hal tersebut menunjukkan bahwa semakin rendahnya likuiditas Bank Maybank Syariah karena jumlah dana dari masayarakat yang disalurkan ke kredit terlalu besar. FDR terendah dimiliki oleh Bank Victoria Syariah dengan nilai FDR sebesar $72.02 \%$ dengan predikat Sangat Sehat karena rendahnya kredit yang dimiliki Bank Victoria Syariah.

Tabel 10 Kesehatan Bank Syariah Berdasarkan Rasio FDR

\begin{tabular}{|c|c|c|c|c|c|c|c|c|c|}
\hline \multirow{2}{*}{ No. } & \multirow{2}{*}{$\begin{array}{l}\text { Nama Bank Umum } \\
\text { Syariah Indonesia }\end{array}$} & \multicolumn{5}{|c|}{$\begin{array}{l}\text { Financing to Deposit Ratio } \\
\text { (FDR/LDR) }\end{array}$} & \multirow[t]{2}{*}{ Rata $^{2}$} & \multirow{2}{*}{ Predikat } & \multirow{2}{*}{ PK } \\
\hline & & 2012 & 2013 & 2014 & 2015 & 2016 & & & \\
\hline 1 & Bank Muamalat & 73.67 & 71.38 & 71.52 & 100.40 & 123.11 & 88.01 & Cukup Sehat & 3 \\
\hline 2 & Bank Syariah Mandiri & 88.07 & 79.41 & 78.93 & 114.60 & 144.58 & 101.12 & Kurang Sehat & 4 \\
\hline 3 & Bank Mega Syariah & 82.62 & 80.44 & 101.07 & 155.88 & 186.93 & 121.39 & Tidak Sehat & 5 \\
\hline 4 & Bank BRI Sya & 86.50 & 80.26 & 79.12 & 105.62 & 126.83 & 95.67 & Cuku & 3 \\
\hline 5 & Bank Syariah Bukopin & 78.72 & 73.07 & 75.17 & 106.74 & 122.80 & 91.30 & Cukup Sehat & 3 \\
\hline 6 & Bank Panin Syariah & 91.80 & 58.40 & 72.06 & 87.79 & 79.64 & 77.94 & Sehat & 4 \\
\hline 7 & Bank Victoria Syariah & 60.58 & 57.20 & 74.17 & 88.29 & 79.88 & 72.02 & Sangat Sehat & 1 \\
\hline 8 & Bank BCA Syariah & 69.87 & 65.25 & 69.97 & 74.98 & 82.65 & 72.54 & Sangat Sehat & 1 \\
\hline 9 & Bank & 80.89 & 80.36 & 72.86 & 146.58 & 185.46 & 113.23 & Kurang Sehat & 4 \\
\hline 10 & Bank BNI Syariah & 72.45 & 64.84 & 71.58 & 129.88 & 164.58 & 100.67 & Kurang Sehat & 4 \\
\hline 11 & Bank Maybank Syariah & 125.76 & 111.80 & 113.58 & 244.18 & 335.70 & 186.20 & Tidak Sehat & 5 \\
\hline & RAT T & 82.81 & 74.77 & 80.00 & 123.18 & 148.38 & 101.83 & Kurang Sehat & 4 \\
\hline
\end{tabular}




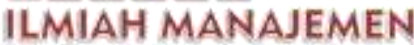 \\ ISSN (print) : 2598-9545 \& ISSN (online) : 2599-171X \\ FORKAMMA}

JणRNAL

Sumber: Data diolah (2018)

\section{Analisis Good Corporate Governance (GCG)}

Hasil analisis self assessment Bank Syariah berdasarkan Tabel 11 menunjukkan bahwa rata-rata secara keseluruhan Good Corporate Governance (GCG) Bank Umum Syariah (BUS) yaitu dengan Nilai Komposit 1.83\% dengan predikat Baik selama tahun 2012-2016 mendapat peringkat dua dengan rata-rata penerapan GCG secara umum baik, GCG tertinggi dimiliki oleh Bank BJB Syariah dengan nilai rata-rata GCG Nilai Komposit sebesar $2.31 \%$ dengan predikat Baik Hal tersebut menunjukkan bahwa semakin rendahnya Good Corporate Governance Bank BJB Syariah. GCG terendah dimiliki oleh Bank BCA Syariah dengan nilai GCG Nilai Komposit sebesar 1.32\% dengan predikat Sangat Baik mendapat peringkat satu Hal tersebut menunjukkan bahwa semakin tingginya Good Corporate Governance Bank BCA Syariah.

Tabel 11 Kesehatan Bank Syariah Berdasarkan Rasio GCG

\begin{tabular}{|c|l|c|c|c|c|c|c|c|c|}
\hline \multirow{2}{*}{ No. } & \multirow{2}{*}{$\begin{array}{l}\text { Nama Bank Umum } \\
\text { Syariah Indonesia }\end{array}$} & \multicolumn{5}{|c|}{ Good Corporate Governance } & \multirow{2}{*}{ Rata $^{2}$} & \multirow{2}{*}{ Predikat } & \multirow{2}{*}{ PK } \\
\cline { 3 - 9 } & & $\mathbf{2 0 1 2}$ & $\mathbf{2 0 1 3}$ & $\mathbf{2 0 1 4}$ & $\mathbf{2 0 1 5}$ & $\mathbf{2 0 1 6}$ & & & \\
\hline 1 & Bank Muamalat & 1.15 & 1.15 & 3.00 & 3.00 & 2.00 & 2.06 & Baik & 2 \\
\hline 2 & Bank Syariah Mandiri & 2.25 & 1.85 & 2.12 & 2.00 & 2.00 & 2.04 & Baik & 2 \\
\hline 3 & Bank Mega Syariah & 1.60 & 1.87 & 2.00 & 1.54 & 1.64 & 1.73 & Baik & 2 \\
\hline 4 & Bank BRI Syariah & 1.38 & 1.35 & 1.74 & 1.61 & 1.60 & 1.54 & Baik & 2 \\
\hline 5 & Bank Syariah Bukopin & 1.50 & 1.50 & 2.00 & 1.50 & 1.50 & 1.60 & Baik & 2 \\
\hline 6 & Bank Panin Syariah & 1.35 & 1.35 & 1.40 & 2.00 & 2.00 & 1.62 & Baik & 2 \\
\hline 7 & Bank Victoria Syariah & 1.69 & 1.66 & 1.93 & 3.00 & 2.49 & 2.15 & Baik & 2 \\
\hline 8 & Bank BCA Syariah & 1.80 & 1.80 & 1.00 & 1.00 & 1.00 & 1.32 & Sangat Baik & 1 \\
\hline 9 & Bank BJB Syariah & 2.53 & 3.00 & 2.00 & 2.00 & 2.00 & 2.31 & Baik & 2 \\
\hline 10 & Bank BNI Syariah & 1.30 & 1.30 & 2.00 & 2.00 & 2.00 & 1.72 & Baik & 2 \\
\hline 11 & Bank Maybank Syariah & 2.00 & 2.00 & 2.00 & 2.00 & 2.00 & 2.00 & Baik & 2 \\
\hline \multicolumn{1}{|c|}{ RATA-RATA } & $\mathbf{1 . 6 9}$ & $\mathbf{1 . 7 1}$ & $\mathbf{1 . 9 3}$ & $\mathbf{1 . 9 7}$ & $\mathbf{1 . 8 4}$ & $\mathbf{1 . 8 3}$ & Baik & $\mathbf{2}$ \\
\hline
\end{tabular}

\section{Analisis Earnings (Rentabilitas)}

Penelitian ini mengukur Analisis Earnings (Rentabilitas) pada faktor earnings menggunakan Return On Asset (ROA), Net Interest Margin (NIM) dan Beban \& Pendapatan Operasional (BOPO) sebagai berikut :

a. Return On Asset (ROA),

Berdasarkan Tabel 12 menunjukkan bahwa rata-rata secara keseluruhan Return On Asset (ROA) Bank Umum Syariah (BUS) yaitu $0.13 \%$ dengan predikat Kurang Sehat dengan nilai PK 4. ROA tertinggi dimiliki oleh Bank Mega Syariah dengan nilai rata-rata $\mathrm{ROA}$ sebesar $1.95 \%$ dengan predikat Sehat dengan nilai PK 2, karena meningkatnya pendapatan atas aset di Bank Mega Syariah. ROA terendah dimiliki oleh Bank Maybank Syariah dengan nilai ROA sebesar $-4.23 \%$ dengan predikat Tidak Sehat karena pendapatan atas aset di Bank Maybank Syariah.

Tabel 12 Kesehatan Bank Berdasarkan Rasio ROA

\begin{tabular}{|c|l|c|c|c|c|c|c|c|c|}
\hline \multirow{2}{*}{ No. } & \multirow{2}{*}{$\begin{array}{l}\text { Nama Bank Umum } \\
\text { Syariah Indonesia }\end{array}$} & \multicolumn{5}{|c|}{ Return On Asset (ROA) } & \multirow{2}{*}{ Rata $^{2}$} & \multirow{2}{*}{ Predikat $^{*}$ PK } \\
\cline { 3 - 11 } & $\mathbf{2 0 1 2}$ & $\mathbf{2 0 1 3}$ & $\mathbf{2 0 1 4}$ & $\mathbf{2 0 1 5}$ & $\mathbf{2 0 1 6}$ & & & \\
\hline 1 & Bank Muamalat & 0.92 & 0.96 & 0.19 & 0.22 & 0.21 & 0.50 & Cukup Sehat & 3 \\
\hline 2 & Bank Syariah Mandiri & 1.49 & 1.27 & 0.11 & 0.35 & 0.35 & 0.71 & Cukup Sehat & 3 \\
\hline 3 & Bank Mega Syariah & 3.13 & 2.29 & 0.34 & 0.27 & 3.75 & 1.95 & Sehat & 2 \\
\hline
\end{tabular}


ISSN (print) : 2598-9545 \& ISSN (online) : 2599-171X

\begin{tabular}{|c|c|c|c|c|c|c|c|c|c|}
\hline 4 & Bank BRI Syariah & 0.98 & 0.74 & 0.12 & 0.49 & 0.62 & 0.59 & Cukup Sehat & 3 \\
\hline 5 & Bank Syariah Bukopin & 0.73 & 0.63 & 0.25 & 0.63 & 0.76 & 0.60 & Cukup Sehat & 3 \\
\hline 6 & Bank Panin Syariah & 1.41 & 0.89 & 1.11 & 0.78 & 0.30 & 0.90 & Cukup Sehat & 3 \\
\hline 7 & Bank Victoria Syariah & 1.21 & 0.31 & -0.48 & -0.57 & -1.46 & -0.20 & Tidak Sehat & 5 \\
\hline 8 & Bank BCA Syariah & 0.51 & 0.61 & 0.44 & 0.55 & 0.56 & 0.53 & Cukup Sehat & 3 \\
\hline 9 & Bank BJB Syariah & 0.49 & 0.60 & 0.37 & 0.11 & -5.57 & -0.80 & Tidak Sehat & 5 \\
\hline 10 & Bank BNI Syariah & 1.08 & 0.77 & 0.84 & 0.96 & 0.96 & 0.92 & Cukup Sehat & 3 \\
\hline 11 & Bank Maybank Syariah & 2.76 & 2.06 & 2.22 & -17.73 & -0.47 & -4.23 & Tidak Sehat & 5 \\
\hline & RATA-RATA & 1.34 & 1.01 & 0.50 & -1.27 & -0.91 & 0.13 & Kurang Sehat & 4 \\
\hline
\end{tabular}

\section{b. Net Interest Margin (NIM)}

Berdasarkan Tabel 13 menunjukkan bahwa rata-rata secara keseluruhan Net Interest Margin (NIM) Bank Umum Syariah (BUS) yaitu $5.70 \%$ dengan predikat Sangat Sehat dengan nilai PK 1. NIM tertinggi dimiliki oleh Bank Mega Syariah dengan nilai rata-rata NIM sebesar $9.97 \%$ dengan predikat Sangat Sehat nilai PK 1 karena meningkatnya jumlah pendapatan bunga bersih Bank Mega Syariah. NIM terendah dimiliki oleh Bank Victoria Syariah dengan nilai NIM sebesar $3.00 \%$ dengan predikat Sehat nilai PK 2 karena rendahnya pendapatan bunga bersih yang dimiliki Bank Victoria Syariah.

Tabel 13 Kesehatan Bank Berdasarkan Rasio NIM

\begin{tabular}{|c|l|c|c|c|c|c|c|c|c|}
\hline \multirow{2}{*}{ No. } & Nama Bank Umum & \multicolumn{5}{|c|}{ Net Interest Margin (NIM) } & \multirow{2}{*}{ Rata $^{2}$} & \multirow{2}{*}{ Predikat } & \multirow{2}{*}{ PK } \\
\cline { 3 - 8 } & Syariah Indonesia & $\mathbf{2 0 1 2}$ & $\mathbf{2 0 1 3}$ & $\mathbf{2 0 1 4}$ & $\mathbf{2 0 1 5}$ & $\mathbf{2 0 1 6}$ & & & \\
\hline 1 & Bank Muamalat & 4.64 & 4.64 & 3.36 & 4.09 & 3.21 & 3.99 & Sangat Sehat & 1 \\
\hline 2 & Bank Syariah Mandiri & 7.25 & 7.25 & 6.20 & 5.75 & 6.16 & 6.52 & Sangat Sehat & 1 \\
\hline 3 & Bank Mega Syariah & 13.94 & 10.66 & 8.33 & 9.34 & 7.56 & 9.97 & Sangat Sehat & 1 \\
\hline 4 & Bank BRI Syariah & 7.33 & 6.27 & 6.04 & 6.38 & 6.37 & 6.48 & Sangat Sehat & 1 \\
\hline 5 & Bank Syariah Bukopin & 3.06 & 3.86 & 2.75 & 3.14 & 3.31 & 3.22 & Sangat Sehat & 1 \\
\hline 6 & Bank Panin Syariah & 4.14 & 3.15 & 4.38 & 4.06 & 3.37 & 3.82 & Sangat Sehat & 1 \\
\hline 7 & Bank Victoria Syariah & 2.36 & 2.96 & 3.34 & 3.89 & 2.43 & 3.00 & Sehat & 2 \\
\hline 8 & Bank BCA Syariah & 5.40 & 5.00 & 4.20 & 4.90 & 4.80 & 4.86 & Sangat Sehat & 1 \\
\hline 9 & Bank BJB Syariah & 7.41 & 6.65 & 4.88 & 5.68 & 4.64 & 5.85 & Sangat Sehat & 1 \\
\hline 10 & Bank BNI Syariah & 11.03 & 9.51 & 8.15 & 8.25 & 8.32 & 9.05 & Sangat Sehat & 1 \\
\hline 11 & Bank Maybank Syariah & 5.78 & 5.61 & 6.65 & 6.54 & 4.99 & 5.91 & Sangat Sehat & 1 \\
\hline & \multicolumn{1}{|c|}{ RATA-RATA } & $\mathbf{6 . 5 8}$ & $\mathbf{5 . 9 6}$ & $\mathbf{5 . 3 0}$ & $\mathbf{5 . 6 4}$ & $\mathbf{5 . 0 1}$ & $\mathbf{5 . 7 0}$ & Sangat Sehat & $\mathbf{1}$ \\
\hline
\end{tabular}

\section{c. Beban Operasional, Pendapatan Operasional (BOPO)}

Berdasarkan Tabel 14 menunjukkan bahwa rata-rata secara keseluruhan Beban Operasional dengan Pendapatan Operasional (BOPO) Bank Umum Syariah (BUS) yaitu $94.91 \%$ dengan predikat Kurang Sehat dengan nilai PK 4. BOPO tertinggi dimiliki oleh Bank Maybank Syariah dengan nilai rata-rata BOPO sebesar 109.13\% dengan predikat Tidak Sehat dengan nilai PK 5 karena meningkatnya Beban Operasional Bank Maybank Syariah. BOPO terendah dimiliki oleh Bank Panin Syariah dengan nilai BOPO sebesar $86.02 \%$ dengan predikat Sangat Sehat dengan nilai PK 1 karena rendahnya Beban Operasional yang dimiliki Bank Panin Syariah. 
Tabel 14 Kesehatan Bank Berdasarkan Rasio BOPO

\begin{tabular}{|c|c|c|c|c|c|c|c|c|c|}
\hline \multirow[t]{2}{*}{ No. } & \multirow{2}{*}{$\begin{array}{l}\text { Nama Bank Umum } \\
\text { Syariah Indonesia }\end{array}$} & \multicolumn{5}{|c|}{$\begin{array}{c}\text { Beban \& Pendapatan Operasional } \\
\text { (BOPO) }\end{array}$} & \multirow[t]{2}{*}{ Rata $^{2}$} & \multirow{2}{*}{ Predikat } & \multirow[t]{2}{*}{ PK } \\
\hline & & 2012 & 2013 & 2014 & 2015 & 2016 & & & \\
\hline 1 & Bank Muamalat & 83.83 & 84.97 & 97.89 & 97.13 & 97.95 & 92.35 & Sangat Sehat & 1 \\
\hline 2 & Bank Syariah Mandiri & 81.87 & 83.98 & 98.60 & 96.88 & 94.11 & 91.09 & Sangat Sehat & 1 \\
\hline 3 & Bank Mega Sy & 80.35 & 88.56 & 98.32 & \begin{tabular}{|l|}
99.73 \\
\end{tabular} & 90.26 & 91.44 & Sangat Sehat & 1 \\
\hline 4 & Bank BRI Sy & 91.31 & 90.44 & 98.89 & 93.75 & 91.55 & 93.19 & $\mathrm{Sa}$ & 1 \\
\hline 5 & Bank Syariah Bukopin & 90.96 & 92.23 & 96.68 & 91.97 & 89.41 & 92.25 & Sangat Sehat & 1 \\
\hline 6 & Bank Panin Syariah & 74.90 & 84.22 & 85.75 & 89.66 & 95.57 & 86.02 & Sangat Sehat & 1 \\
\hline 7 & Bank Victoria Syariah & 90.67 & 96.05 & 104.23 & 102.34 & 125.52 & 103.76 & Tidak Sehat & 5 \\
\hline 8 & Bank BCA Syariah & 93.51 & 91.71 & 93.71 & 94.15 & 93.75 & 93.36 & Sangat Sehat & 1 \\
\hline 9 & Bank BJB Syariah & 94.42 & 101.57 & 95.21 & 99.39 & 122.77 & 102.67 & Tidak Sehat & 5 \\
\hline 10 & Bank BNI Syariah & 87.67 & 88.45 & 89.79 & 90.05 & 87.67 & 88.73 & Sangat Sehat & 1 \\
\hline 11 & Bank Maybank Syariah & 65.22 & 69.04 & 73.84 & 183.89 & 153.69 & 109.13 & Tidak Sehat & 5 \\
\hline & RATA-RATA & 7 & 88.29 & 93.90 & 103.54 & 103.84 & 94.91 & Kurang Sehat & 4 \\
\hline
\end{tabular}

Sumber: Data diolah $(2018$

\section{Analisis Capital ( Permodalan )}

Hasil analisis capital Bank Syariah Tabel 15 menunjukkan bahwa rata-rata secara keseluruhan Capital Adequency Ratio (CAR) Bank Umum Syariah (BUS) yaitu 20.94\% dengan predikat Sangat Sehat dengan nilai PK 1 yang berarti seluruh Bank Umum Syariah (BUS) mampu untuk memenuhi KPMM terbukti dengan seluruh bank mendapat peringkat satu dengan predikat sangat sehat. CAR tertinggi dimiliki oleh Bank Maybank Syariah dengan nilai rata-rata CAR sebesar $49.85 \%$ dengan predikat Sangat Sehat dengan nilai PK 1 karena meningkatnya kecukupan modal Bank Maybank Syariah. CAR terendah dimiliki oleh Bank Syariah Mandiri dengan nilai CAR sebesar $13.78 \%$ dengan predikat Sangat Sehat dengan nilai PK 1 karena rendahnya kecukupan modal yang dimiliki Bank Syariah Mandiri.

Tabel 15 Kesehatan Bank Berdasarkan Rasio CAR

\begin{tabular}{|c|l|c|c|c|c|c|c|c|c|}
\hline \multirow{2}{*}{ No. } & Nama Bank Umum & \multicolumn{3}{|c|}{ Capital Adequency Ratio (CAR) } & \multirow{2}{*}{ Rata $^{2}$} & \multirow{2}{*}{ Predikat } & \multirow{2}{*}{ PK } \\
\cline { 3 - 7 } & Syariah Indonesia & $\mathbf{2 0 1 2}$ & $\mathbf{2 0 1 3}$ & $\mathbf{2 0 1 4}$ & $\mathbf{2 0 1 5}$ & $\mathbf{2 0 1 6}$ & & & \\
\hline 1 & Bank Muamalat & 11.57 & 15.87 & 14.15 & 14.57 & 14.57 & 14.15 & Sangat Sehat & 1 \\
\hline 2 & Bank Syariah Mandiri & 13.82 & 14.10 & 14.12 & 12.85 & 14.01 & 13.78 & Sangat Sehat & 1 \\
\hline 3 & Bank Mega Syariah & 16.83 & 15.74 & 15.23 & 22.86 & 26.21 & 19.37 & Sangat Sehat & 1 \\
\hline 4 & Bank BRI Syariah & 10.90 & 14.10 & 12.53 & 15.85 & 16.95 & 14.07 & Sangat Sehat & 1 \\
\hline 5 & Bank Syariah Bukopin & 12.78 & 11.10 & 14.80 & 16.31 & 15.25 & 14.05 & Sangat Sehat & 1 \\
\hline 6 & Bank Panin Syariah & 32.33 & 20.82 & 25.39 & 24.13 & 26.11 & 25.75 & Sangat Sehat & 1 \\
\hline 7 & Bank Victoria Syariah & 18.08 & 18.40 & 15.27 & 16.14 & 15.98 & 16.77 & Sangat Sehat & 1 \\
\hline 8 & Bank BCA Syariah & 31.50 & 22.40 & 29.60 & 34.30 & 36.70 & 30.90 & Sangat Sehat & 1 \\
\hline 9 & Bank BJB Syariah & 14.85 & 15.46 & 16.95 & 13.85 & 11.00 & 14.42 & Sangat Sehat & 1 \\
\hline 10 & Bank BNI Syariah & 14.22 & 16.54 & 18.76 & 18.16 & 18.20 & 17.18 & Sangat Sehat & 1 \\
\hline 11 & Bank Maybank Syariah & 63.89 & 59.41 & 52.14 & 38.40 & 35.40 & 49.85 & Sangat Sehat & 1 \\
\hline & \multicolumn{1}{|c|}{ RATA-RATA } & $\mathbf{2 1 . 8 9}$ & $\mathbf{2 0 . 3 6}$ & $\mathbf{2 0 . 8 1}$ & $\mathbf{2 0 . 6 7}$ & $\mathbf{2 0 . 9 4}$ & $\mathbf{2 0 . 9 4}$ & Sangat Sehat & $\mathbf{1}$ \\
\hline
\end{tabular}




\section{Analisa Metode Risk Based Bank Rating (RBBR)}

Hasil Metode Risk Based Bank Rating (RBBR) Bank Syariah Tabel 16 menunjukkan bahwa rata-rata tingkat kesehatan Bank Umum Syariah (BUS) yang terdaftar di Otoritas Jasa Keuangan (OJK) dinilai dengan metode Risk Based Bank Rating (RBBR) tahun 2012-2016) di Indonesia yaitu nilai PK 1 dengan predikat Cukup Sehat. berdasarkan Pasal 2 Peraturan bank Indonesia No. 13/1/PBI/2011 dan sesuai yang telah dijelaskan dalam SE BI No. 13/24/DPNP 25 Oktober 2011,metode RBBR ini menitikberatkan pertimbangan kesehatan bank umum berdasarkan prinsip kehatihatian dan manajemen resiko.

Tabel 16 Kesehatan Bank Metode Risk Based Bank Rating (RBBR) Berdasarkan Industri Perbankan Syariah di Indonesia

\begin{tabular}{|c|c|c|c|c|c|c|c|c|c|}
\hline \multirow{2}{*}{ No. } & \multirow{2}{*}{$\begin{array}{c}\text { Pengukuran } \\
\text { Keuangan }\end{array}$} & \multicolumn{5}{|c|}{ Risk Based Bank Rating (RBBR) } & \multirow{2}{*}{ Rata $^{2}$} & \multirow{2}{*}{ Predikat } & \multirow{2}{*}{ PK } \\
\hline & & 2012 & 2013 & 2014 & 2015 & 2016 & & & \\
\hline 1 & $\begin{array}{l}\text { Non Performing Loan } \\
\text { (NPL/NPF) }\end{array}$ & 2.51 & 2.87 & 4.22 & 4.67 & 3.54 & 3.56 & Sehat & 4 \\
\hline 2 & $\begin{array}{l}\text { Loan to Deposit } \\
\text { Ratio (LDR/FDR) }\end{array}$ & 82.81 & 74.77 & 80.00 & 123.18 & 148.38 & 101.83 & Kurang Sehat & 4 \\
\hline 3 & $\begin{array}{l}\text { Good Corporate } \\
\text { Governance (GCG) }\end{array}$ & 1.69 & 1.71 & 1.93 & 1.97 & 1.84 & 1.83 & Baik & 2 \\
\hline 4 & $\begin{array}{l}\text { Return On Asset } \\
\text { (ROA) }\end{array}$ & 1.34 & 1.01 & 0.50 & -1.27 & -0.91 & 0.13 & Kurang Sehat & 4 \\
\hline 5 & $\begin{array}{l}\text { Net Interest Margin } \\
\text { (NIM) }\end{array}$ & 6.58 & 5.96 & 5.30 & 5.64 & 5.01 & 5.70 & Sangat Sehat & 1 \\
\hline 6 & $\begin{array}{l}\text { Beban \& Pendapatan } \\
\text { Operasional (BOPO) }\end{array}$ & 84.97 & 88.29 & 93.90 & 103.54 & 103.84 & 94.91 & Kurang Sehat & 4 \\
\hline \multirow[t]{2}{*}{7} & $\begin{array}{l}\text { Capital Adequency } \\
\text { Ratio (CAR) }\end{array}$ & 21.89 & 20.36 & 20.81 & 20.67 & 20.94 & 20.94 & Sangat Sehat & 1 \\
\hline & \multicolumn{7}{|c|}{ KESEHATAN INDUSTRI } & Cukup Sehat & 2.86 \\
\hline
\end{tabular}

G. Kesimpulan dan Saran

Sumber: Data diolah (2018)

\section{Kesimpulan}

Berdasarkan analisis kesehatan Bank Umum Syariah (BUS) di Indonesia menggunakan metode Risk Based Bank Rating (RBBR) menggunakan rasio NPL, LDR, ROA, NIM, BOPO dan CAR serta publikasi hasil self assesment GCG sebagai berikut :

a) Analisis Kesehatan Bank Umum Syariah (BUS) di Indonesia dengan faktor risk profile atas resiko kredit dengan rasio rata-rata secara keseluruhan NPF dengan predikat Sehat. NPF tertinggi dimiliki oleh Bank Victoria Syariah dengan predikat Cukup Sehat. NPF terendah dimiliki oleh Bank BCA Syariah dengan predikat Sangat Sehat. Risiko Likuiditas menunjukkan bahwa rata-rata secara keseluruhan Financing to Deposit Ratio (FDR/LDR) dengan predikat Kurang Sehat. FDR tertinggi dimiliki oleh Bank Maybank Syariah predikat Tidak Sehat. FDR terendah dimiliki oleh Bank Victoria Syariah dengan predikat Sangat Sehat.

b) Analisis Kesehatan Bank Umum Syariah (BUS) di Indonesia dengan faktor Good Coorporate Governance diperoleh hasil analisis self assessment Bank Syariah berdasarkan rata-rata secara keseluruhan Good Corporate Governance (GCG) yaitu dengan Nilai Komposit 1.83\% dengan predikat Baik selama tahun 2012-2016 mendapat peringkat dua, GCG tertinggi dimiliki oleh Bank BJB Syariah Syariah dengan nilai rata-rata GCG Nilai Komposit sebesar 2.31\% dengan predikat. GCG terendah dimiliki oleh Bank BCA Syariah dengan nilai GCG Nilai Komposit sebesar 
$1.32 \%$ dengan predikat Sangat Baik artinya bank mampu menjalankan secara baik prinsip-prinsip governance system yang terdiri dari governance structure, governance process dan governance outcome serta 11 (sebelas) faktor penilaian pelaksanaan Good Coorporate Governance.

c) Analisis Kesehatan Bank Umum Syariah (BUS) di Indonesia dengan faktor Earning (Rentabilitas) dengan ROA, NIM dan BOPO. Analisis rasio ROA terdapat rata-rata secara keseluruhan Return On Asset (ROA) Bank Umum Syariah (BUS) yaitu predikat Kurang Sehat dengan nilai PK 4. ROA tertinggi dimiliki oleh Bank Mega Syariah dengan predikat Sehat dengan nilai PK 2. ROA terendah dimiliki oleh Bank Maybank Syariah dengan predikat Tidak Sehat. Analisis rasio NIM rata-rata secara keseluruhan Net Interest Margin (NIM) dengan predikat Sangat Sehat dengan nilai PK 1. NIM tertinggi dimiliki oleh Bank Mega Syariah dengan predikat Sangat Sehat nilai PK 1, NIM terendah dimiliki oleh Bank Victoria Syariah dengan predikat Sehat nilai PK 2. Analisis rasio BOPO rata-rata secara keseluruhan Beban Operasional dengan Pendapatan Operasional (BOPO) dengan predikat Kurang Sehat dengan nilai PK 4. BOPO tertinggi dimiliki oleh Bank Maybank Syariah dengan predikat Tidak Sehat dengan nilai PK 5, BOPO terendah dimiliki oleh Bank Panin Syariah dengan predikat Sangat Sehat dengan nilai PK 1.

d) Analisis Kesehatan Bank Umum Syariah (BUS) di Indonesia dengan faktor Capital (Permodalan) diukur dengan rata-rata secara keseluruhan Capital Adequency Ratio (CAR) Bank Umum Syariah (BUS) dengan predikat Sangat Sehat dengan nilai PK 1. CAR tertinggi dimiliki oleh Bank Maybank Syariah dengan predikat Sangat Sehat dengan nilai PK 1, CAR terendah dimiliki oleh Bank Syariah Mandiri dengan predikat Sangat Sehat dengan nilai PK 1.

e) Analisis Kesehatan Bank Umum Syariah (BUS) di Indonesia dengan Metode Risk Based Bank Rating (RBBR) menunjukkan nilai PK 1 dengan predikat Cukup Sehat. berdasarkan Pasal 2 Peraturan bank Indonesia No. 13/1/PBI/2011 dan sesuai yang telah dijelaskan dalam SE BI No. 13/24/DPNP 25 Oktober 2011,metode RBBR ini menitikberatkan pertimbangan kesehatan bank umum berdasarkan prinsip kehatihatian dan manajemen resiko.

\section{Saran}

Adapun saran yang dapat diberikan oleh peneliti atas penelitian yang telah dilakukan adalah sebagai berikut:

a) Kondisi Risk Profile atas resiko kredit dengan rasio NPL dan resiko likuiditas dengan rasio LDR untuk bank yang memperoleh predikat tidak sehat, kurang sehat dan cukup sehat sebaiknya bank harus berhati-hati dalam hal penyaluran kredit karena semakin besar kredit yang diberikan apabila tidak diimbangi dengan manajemen kredit yang baik akan berpotensi menimbulkan risiko kredit maupun risiko likuiditas yang dapat mengganggu kesehatan bank tersebut, dan yang sudah mendapat predikat sangat sehat atau sehat harus dipertahankan agar menjaga tingkat kesehatan bank.

b) Kondisi GCG Bank BJB Syariah dengan predikat kurang baik harus memperhatikan kondisi GCG perusahaan bank agar menjadi lebih baik.

c) Kondisi Earnings (Rentabilitas) diukur dengan NIM perlu dijaga dan dipertahankan serta ditingkatkan, ROA dan BOPO menunjukan Bank Maybank Syariah berpredikat tidak sehat, bank harus meperhatikan tingkat efisiensi biaya dan mengurangi resiko kredit dan likuiditas agar memperoleh keuntungan.

d) Kondisi Capital (Permodalan) bank diukur menggunakan Capital Adequacy Ratio (CAR) mendapat predikat secara keseluruhan rata- rata sangat sehat, sebaiknya terus dipertahankan oleh manajemen bank agar kesehatan bank yang dinilai menggunakan metode Risk Based Bank Rating (RBBR) tetap terjaga. 
e) Penelitian ini hanya menganalisis tingkat kesehatan bank dengan metode Risk Based Bank Rating (RBBR) dengan empat faktor, yaitu faktor Risk Profile sesuai dengan ketentuan Bank Indonesia atas delapan resiko, namun pada penelitian ini menggunakan resiko kredit dan resiko likuiditas, faktor Good Coorporate Governance, faktor Earnings, dan faktor capital. Sehingga dalam menganalisis tingkat kesehatan bank peneliti belum mampu mengkompositkan tingkat kesehatan bank yang diwakili oleh empat faktor secara keseluruhan metode Risk Based Bank Rating (RBBR), dan diharapkan pada penelitian selanjutnya menggambarkan kesehatan bank yang sesuai Surat Edaran BI No 13/24/DPNP mengenai penilaian tingkat kesehatan bank metode Risk Based Bank Rating (RBBR).

\section{Daftar Pustaka}

Antonio, Muhammad Syafi"i, (2001), Bank Syariah dari Teori ke Praktek., Gema Insani Press, Jakarta

Bank Indonesia. (2012). Peraturan Bank Indonesia Nomor: 14/2/PBI/2012 tentang Perubahan atas PBI Nomor:11/11/PBI/2009 tentang Kegiatan Alat Pembayaran dengan Menggunakan Kartu.

Husaini, Ardian, et. al., (2013), Filsafat IImu Perspektif Barat dan Islam, Gema Insani,Jakarta

Kasmir, (2013). Dasar-dasar Perbankan, Raja Grafindo Persada, Jakarta 2010.

Kasmir. (2013). Bank dan Lembaga Keuangan Lainnya. PT Raja Grafindo Persada

Machmud, Amir dan Rukmana. (2010). Bank Syariah Teori, Kebijakan, dan Studi Empiris di Indonesia. Jakarta: Erlangga.

Nachrowi, Djalal Nachrowi, Hardius Usman. (2006). Pendekatan Populer dan Praktis Ekonometruka untuk Analisis Ekonomi dan Keuangan, Lembaga Penerbit Universitas Indonesia, Jakarta

Otoritas Jasa Keuangan, (2015), Roadmap Perbankan Syariah Indonesia 2015-2019, Departemen Perbankan Syariah OJK, Jakarta

(2016), Statistik Perbankan Sariah, Per Maret 2016, <http://www.ojk.go.id/id/kanal/syariah/data-danstatistik/statistiperbankan-

syariah/Pages/Statistik-Perbankan-Syariah---Januari-2016.aspx>

Peraturan Perundang-undangan, 1992, Undang-undang Republik Indonesia Tahun 1992 Tentang Perbankan, DPR-RI, Jakarta

(2008), Undang-undang Republik Indonesia Nomor 21

Tahun 2008 Tentang Perbankan Syariah, DPR-RI, Jakarta

Riyadi Slamet, (2006). Banking Assets and Liability Management (Edisi Ketiga). Jakarta: Lembaga Penerbit Fakultas Ekonomi Universitas Indonesia, 2006.

Sumitro, Warkum. (2004), Asas-asas Perbankan Islam dan Lembaga Terkait, Rajawali Press, Jakarta

Sunann Ibn Majah kitab Al-Muqoddimah bab Fadl Al-Ulama wa al-hasts ala talab al-ilm no,224. (Abu Abdillah Muhammad ibn Yazid al-Qazwini, sunan Ibn Majah, Beirut:Dar al-Fikr, 1995, Jilid 1, hal. 81)

Taswan. (2010). Manajemen Perbankan, Konsep, Teknik, dan Aplikasi. Edisi Kedua. Yogyakarta : UPP STIM YKPN.

Zuhal. (2010). Knowledge \& Inovation sebagai Platform Kekuatan Daya Saing. PT. Gramedia Pustaka Utama, Jakarta

Brigham \& Houston. (2010) Dasar - Dasar Manajemen Keuangan (Essentials Of Financial Management). Edisi ke - 11. Salemba Empat. Jakarta. (Diterjemahkan oleh Ali Akbar Yulianto).

Muthaher (2012). Akuntansi Perbankan Syariah.Yogyakarta. Graha Ilmu.

Yaya, R. A, E. Martawireja, dan Ahim, A. (2014). Akuntansi Perbankan Syariah teori dan Praktik Kontemporer. Salemba Empat. Jagakarsa-Jakarta Selatan. 
Andi Widiyanto (2015). Analisis Tingkat Kesehatan Bank Dengan Menggunakan Metode Risk Based Bank Rating (RBBR) (Studi pada Bank yang terdaftar di Bursa Efek Indonesia dalam IHSG Sub Sektor Perbankan Tahun 2012 - 2014). Program Studi Manajemen - S1, Fakultas Ekonomi \& Bisnis, Universitas Dian Nuswantoro Semarang

Freddy L. Sihombing dan Yusuf Budiana (2015). Pengaruh Kesehatan Bank Menggunakan Metode Risk Based Bank Rating Terhadap Harga Saham Perusahaan Perbankan Yang Go Public Di Bursa Efek Indonesia Tahun 2009-2014. e-Proceeding of Management : Vol.2, No.3 Desember 2015 | Page 2428, ISSN : 2355-9357, UniversitasTelkom.

Nardi Sunardi (2017), Determinan Intelectual Capital dengan Pendekatan iB-VAIC TM Terhadap Efisiensi Biaya Implikasinya Pada Profitabilitas Perbankan Syariah di Indonesia, Jurnal Sekuritas (Saham, Ekonomi, Keuangan dan Investasi), Vol.1, No.2 , Desember 2017, Unversitas Pamulang.

Alizatul Fadhila, M. Saifi dan Zahroh Z.A (2015). Analisis Tingkat Kesehatan Bank Dengan Menggunakan Metode Risk Based Bank Rating (RBBR) (Studi pada Bank Milik Pemerintah Pusat yang Terdaftar di Bursa Efek Indonesia Tahun 2011-2013). Jurnal Administrasi Bisnis (JAB), Vol. 2 No. 1 Februari 2015, Universitas Brawijaya, Malang.

Gustina (2015). Tinjauan Kesehatan Bank Melalui Metode Risk Based Bank Rating, Polibisnis, Volume 7 No.1 April 2015, ISSN 1858-3717, Politeknik Negeri Padang.

Bank Indonesia. (2017). "Publikasi Bank", diakses pada tangal 01 September 2017 dari http://www.bi.go.id/publikasi/dpi/default.aspx. 